\title{
Duša u Augustinovim Ispovijestima s posebnim osvrtom na problem utvrđivanja (ne)podudarnosti s obzirom na Freudovu koncepciju psihoanalize
}

\author{
Dafne Vidanec*
}

\begin{abstract}
Sažetak
Ovaj rad metodološki je zamišljen kao interdisciplinarno (filozofsko i teološko) promišljanje o duši. Epistemološki većinom se oslanja na spoznajno-teorijske izvore dvojice vrsnih poznavatelja koncepta duše: filozofa, teologa i kršćanskog naučitelja i biskupa sv. Augustina Aurelija (354. — 430.) i austrijskog psihologa, »oca psihoanalize« i pionira sfere nesvjesnog Sigmunda Freuda (1856. - 1939.). $U$ radu želimo propitati konvergencije i divergencije s obzirom na njihov koncept duše.

U radu će se odgovoriti na sljedeće: 1) na koji način Augustin razumijeva pojam duše, odakle polazi i na čemu temelji svoje razumijevanje o duši te 2) do koje mjere i na koji se način Augustinovo učenje o duši, izraženo u njegovim Ispovijestima, reflektiralo na Freudovo tumačenju duše shvaćene kao locus primus proučavanja uzroka i posljedica neuropatoloških fenomena u okviru kliničke prakse, detaljno opisane u Uvodu u psihoanalizu.

U prvom dijelu rada, s teološkog i spoznajnog aspekta, propituju se temeljne postavke Augustinova shvaćanja i tumačenja duše, u duhu one Fichteove qualis homo, talis philosophia. Drugi je dio rada usredotočen na autoričinu interpretaciju Freudove psihoanalize kao terapeutske metode pomoću koje ne samo da se proučava nego i liječi čovjekova »bolesna duša«, odnosno »ličnost« (Allport). U trećem dijelu govori se o konvergencijama i divergencijama Augustinove i Freudove »teo-psihoantropologije", jer ono što je zajedničko i Augustinu i Freudu jest fokus njihova istraživanja, a to je čovjek: za Augustina (raz)otkrivanje duše je put (raz)otkrivanja Boga, tako da govorimo o psihologiji koja izvire iz ascendentne teologije, a s druge pak strane, (raz)otkrivanje nesvjesnoga dijela freudovski protumačene Aristotelove »razumske duše" put je otkrivanja čovjekova osobnog identiteta (sebstva): čovjek je ishodišna točka u istraživanju Boga (tj. izvora dobra), ali i sebe samoga (sv. Augustin, Charles Taylor).

Ključne riječi: Aurelije Augustin, Sigmund Freud, duša, psihoanaliza, čovjek, ličnost, psihologija

* Dr. sc. Dafne Vidanec, Veleučilište Baltazar Zaprešić. Adresa: Vladimira Novaka 23, 10290 Zaprešić, Hrvatska. E-pošta: dafne.vidanec@gmail.com
\end{abstract}




\section{Uvod}

[...] poznavanje duše mnogo pridonosi cjelovitoj istini [...], jer duša je kao početak živih bića.

Aristotel, $O$ duši ${ }^{1}$

Motivacija za ovaj rad je vezana za autoričin osobni stav prema kojemu se u današnjem svijetu, kako na lokalnoj, tako i na globalnoj razini, moralna apokalipsa sve više čini očitom, jer se previđa važnost diskursa o onom smislenom i svetom, te govoriti o tim metafizičkim kategorijalnim određenjima ljudske egzistencije augustinovskim jezikom u današnje vrijeme znači, ricoeurovski pojmljeno, »učiniti zamišljen zaokret « (Ch. Taylor) prema »rekonfiguraciji« »autentičnih « moralnih vrijednosti koje oblikuju dušu suvremenog doba. Ovaj rad upravo je nastao iz pobude da se najprije razumiju filozofsko-teološke postavke onoga što u današnje vrijeme na tragu Freuda možemo detektirati kao neuropatološku anomaliju sve-svjetske duše koja vapi za stanovitim »obraćenjem«, jednako kao što je za etičkim aktom te vrste vapio i Augustin potkraj mjeseca travnja daleke 387. godine, tako da diskurs o duši, koji ovdje želimo prezentirati, želi biti poticaj na razmišljanje o tome da razumijevanje onoga što dohvaćamo u pojmu duše traži dubok i jasan uvid u genezu i suštinu onih teorija i učenja u povijesti filozofske misli koje su navlastito obilježile diskurs o duši, i to ne samo na povijesno-epohalnoj, nego primarno na metaetičkoj razini.

\section{Duša u Ispovijestima Sv. Augustina}

\subsection{Augustinov in interiore homine}

U djelu naslovljenom The Nature of Narrative, u okviru sadržaja trećeg poglavlja, raspravljajući o narativnoj biografiji iznijetoj u formi ispovijesti, izrijekom se navodi »da nije bilo Augustina nikada ne bismo imali Freuda «. ${ }^{2}$ Tu je tvrdnju moguće uzeti kao ishodišnu točku u istraživanju i utvrđivanju Augustinovih temelja Freudove koncepcije psihoanalize, što je predmet rasprave u drugom dijelu rada. Kažemo »moguće « jer, iščitavajući Augustinova djela relevantna za razumijevanje njegova učenja o duši s jedne strane te analizirajući Freudove uvide bjelodane u Uvodu u psihoanalizu s druge, nametnuo se zaključak da je Freud u temelju augustinovac i da je Augustin pionir psihoanalize, te da se Freudov doprinos sastoji u tome što je pokazao na koji način Augustinov misaoni konstrukt introspekcije na kojem se temelji psihoanaliza realizira se u praksi.

Govoreći o Augustinu i njegovu nauku općenito, pretpostavlja se da će se mnogi složiti s tvrdnjom da je riječ o čovjeku koji je u misaonom pogledu bio da-

1 Aristotel, O duši : Nagovor na filozofiju, Zagreb, 1996, I., 402a.

2 Robert Scholes - James Phelan — Robert Kellogg, The Nature of Narrative : Revised and Expanded, Oxford, 2006, str. 79. 
leko ispred svojega vremena, a tu zaslugu priznaju mu i značajni suvremeni filozofi heideggerijanske provenijencije poput Ricoeura, komu je upravo Augustinova teorija o vremenu u Ispovijestima rasvijetlila problematiku vremenitosti egzistencije, o čemu Ricoeur raspravlja u svojem trovolumnom djelu Time and Narrative. Augustin je, neumitno možemo tvrditi, prvi »istraživač« kojemu je pošlo za rukom prodrijeti u čovjekovu nutrinu ${ }^{3}-\mathrm{u}$ unutarnji sklop ličnosti, kako bi rekli psiholozi. Što je Augustin učinio? — Ponudio je je jednu metodu razumijevanja i tumačenja čovjeka uz pomoć koje je moguće doprijeti do »unutarnjeg čovjeka« ${ }^{4}$ Augustinov »unutarnji čovjek« je sinonim za dušu — za sebstvo (engl. self). To sebstvo je pronašlo središnje mjesto u kršćanstvu, odnosno kršćanskoj misli koja je prema novozavjetnim zapisima usmjerena na »ozdravljenje « čovjekove grješne duše, i to ozdravljenje, prema Augustinovu shvaćanju bjelodanom u Ispovijesti$m a$ kao i prema shvaćanju interpreta Augustinova učenja, otpočinje obraćenjem koje je »velika Božja milost obraćenu pojedincu i Crkvi, a osobito se to može reći za sv. Augustina jer je njegovo obraćenje urodilo mnogostrukim plodovima za Crkvu kroz stoljeća «. ${ }^{5}$ Ne samo za Crkvu, nego i onkraj prethodno spomenute tvrdnje, Augustinovo obraćenje, ako ga se izuzme izvan religioznog konteksta, ima duboko značenje za razumijevanje konstelacije čovjekove osobe, njegove nutrine, odnosno načina na koji nutrina nekog čovjeka funkcionira, načina na koji je strukturirana, a opet motivi koji nekog čovjeka uvjetno rečeno »natjeraju « na obraćenje, jer obraćenje je, etički promatrano, čin kojemu prethodi slobodna volja potaknuta razumom, saznanjem o smislu i svrsi onoga prema čemu volja stremi, kako je utvrdio i sam Sokrat i njegovi sukcesori: čovjek koji ne uči o tome što je dobro, ne može imati znanja o dobru; utoliko možemo kazati da Augustinovu obraćenju prethodi dugogodišnji spoznajni trening: učenje o Svetom pismu, razmatranja i uvidi koji su proizašli iz toga učenja uz pomoć kojih je Augustin produbio svoje spoznaje o Bogu i vjeri, putem pitanja koja je sâm sebi postavljao: primjerice, što je kršćanstvo, što je duša, tko je Bog i zašto je Krist Njegov »Posrednik«. Kako se prethodno opisano »uklapa« u problematiku duše i gdje je duši mjesto u kontekstu obraćenja? - Prema kršćanskom učenju, čovjekova je duša Božja briga, Bog se brine za čovjekovu dušu, i ta se briga manifestira kao moralna briga za dušu svijeta. Žargonski se može kazati da Bog vodi računa o duši grješnika i duši svijeta. Takav kršćanski pristup, kako stoji u The Nature of Narrative, čije je metodologijske temelje postavio Augustin, ide u smjeru psihologije. Svjedočanstvo o tome, kako se objašnjava u spomenutoj knjizi, a referirajući se na Augustina, moguće je pronaći u Ispovijestima u odlomcima u kojima Augustin govori o ljubomori u djece ${ }^{6}$ koja se očituje u činu krađe iz »podruma svojih

3 Isto.

4 Charles Taylor, Izvori sebstva : Razvoj modernog identiteta, Zagreb, str. 139-153.

5 Anto Mišić, Tisućušestota obljetnica obraćenja sv. Augustina, Obnovljeni život (Zagreb), 42/1 (1987), 69-71; Anto Mišić, Uspon čovjeka do Boga - u »Ispovijestima« sv. Augustina, Obnovljeni život (Zagreb), 47/3-4 (1992), 215-230.

6 Aurelije Augustin, Ispovijesti, Zagreb, 2010, I., 19, II., 4. 
roditelja i sa stola « i susjedova vinograda te o ljubavi prema vlastitoj propasti i grijehu $^{7}$ kao i o požudi »za isticanjem «, gdje se upravo fokusira na sebstvo.

Poteškoću s kojom smo se susreli tijekom pisanja ove studije moguće je formulirati u pitanju: Kako uopće govoriti o duši u perspektivi kršćanske filozofske misli, s jedne strane, i jedne redukcionističke koncepcije čovjeka na kojoj počiva Freudov model psihoanalize, s druge? - U tom smislu pokušao se zaobići princip sučeljavanja argumenata i kontraargumenata obiju strana i pribjeći viđenju koje je moguće domisliti pod velom filozofskog mišljenja, jer ono je dobrodošlo u stvarima, kako je kazivao Gadamer, koje nitko drugi ne razumije doli filozof.

\subsection{Kako razumjeti Augustina kao mislioca?}

Aurelija Augustina kao mislioca koji je na svojstven način obilježio sadržaj ranosrednjovjekovne kršćanske filozofske misli na Zapadu i ne treba posebno predstavljati. Riječ je o vrlo zanimljivoj — da posudimo psihologijski izraz »ličnosti«. O njegovoj osobnosti, karakteru, djetinjstvu, obrazovanju, svjetonazoru i životu najbolji uvid pružaju nam njegove privatne ispovijesti, sabrane u istoimeno cjelovito djelo, odnosno, biografiju. Prema izvornom (latinskom) nazivu Confessiones strukturalno predstavljaju Augustinovu biografiju sažetu i raspoređenu u 13 knjiga. Sadržajno i esencijalno ta se biografija dijeli na dva dijela: prije obraćenja (I. — VII. knjiga) i poslije obraćenja (VIII. — XIII. knjiga).

Ono što je prethodilo Augustinovu obraćenju povezano je s nizom događaja koji su obilježili Augustinov život i o kojima se detaljno može iščitavati u Ispovijestima, tako da o njima na ovom mjestu nećemo govoriti. Možda je presudan događaj koji je uvjetovao obraćenje povezan s metafizičkim zadatostima koje se ponajprije tiču Augustinove majke Monike, koja je, kako stoji u Ispovijesti$m a$, prolila mnogo suza ne bi li se njezin sin — taylorovski rečeno — postavio u »ispravan odnos prema dobru «.

Oslanjajući se na Ispovijesti, problematiku razumijevanja Augustinove osobnosti postavit ćemo na sljedeći način: kao polazište uzet ćemo tri modela koji će nam pomoći pri upoznavanju Augustinove ličnosti te shvaćanju povoda, motiva, smislova i značenja njegova učenja o duši: a) teološki model; b) psihološki model; c) spoznajni model.

\subsubsection{Teološki model}

Augustin, kako je razvidno već na početku Ispovijesti, strepi pred smrtnošću. Ta je strepnja potencirana mišlju o Božjoj veličini spram čovjekove »sićušnosti :8 »I hvaliti te želi čovjek, sićušan djelić tvoga stvorenja, čovjek koji svuda sa sobom nosi svoju smrtnost [...].«9 Augustin svoje »ispovijesti« započinje veličanjem Božje veličine; što i nije u fokusu problematike kojom se ovdje bavimo, ali

7 Aurelije Augustin, Ispovijesti, Zagreb, 201011, II., 6.

8 Aurelije Augustin, Ispovijesti, I., 1.; također usp. Blaise Pascal, Misli, Zagreb, 1969; Hans Küng, Postoji li Bog? Odgovor na pitanje o Bogu u novome vijeku, Zagreb, 1987, str. 52.

9 Aurelije Augustin, Ispovijesti, I., 1. . 
predstavlja vrijedan podatak, temeljem kojega nastojimo dokučiti Augustinovo psihološko stanje u trenutku kada on, hvaleći Boga, strepi pred svojom smrtnošću i konačnošću.

Svjesnost o konačnosti, smrtnosti i sićušnosti njegova bića u Augustinu pobuđuje dvoje: a) žudnju da spozna tko? ili što? se krije iza te »veličine«i b) unutarnju težnju/poriv ili potrebu za komunikacijom, odnosno, za samoočitovanjem. Prvo se ne čini tako začuđujućim u usporedbi s potonjim, koje je prema Aristotelu svojstveno svakomu razumskomu biću i koje razumsko biće čini društvenim. Međutim, ono što je začuđujuće te se čini pomalo ekscentričnim jest činjenica da Augustin želi komunicirati s Bogom i to na način »živog« odnosa, koji traži blizinu druge osobe, povjerenje i — grubo rečeno - povratnu informaciju, te koji je odnos karakterističan za samog čovjeka: dijalog. Drugim riječima, Augustin želi uspostaviti prijateljski odnos s Bogom na način koji je svojstven čovjeku kao takvom. To je samo povod, a cilj je daleko složeniji: Augustin, kao i mnogi drugi mislioci, u suštini traga za »velikom tajnom života«: spoznati besmrtnost u svoj njezinoj formi i sa svim njezinim sadržajem; odnosno, teološki interpretirano, spoznati Boga kao onog koji je sve stvorio i koji je veći od zemlje, od neba, od svega onog što je na zemlji i što se nalazi u moru. ${ }^{10}$ Kompletna Augustinova misaona pustolovina koja nosi naziv Ispovijesti isprepletena je s unutarnjim stanjem njegove osobe, a to stanje Augustin eksplicitno iznosi u X. knjizi, čiji sadržaj u cijelosti ocrtava stanje njegove duše u trenutku kada piše o sebi kao o čovjeku, tako da se u temporalnom pogledu neprekidno isprepliću prošlost i sadašnjost, kako na papiru i u peru, tako i u njegovim mislima i viđenjima zbilje. Uzmimo to stanje duše kao prvu polazišnu točku ili odrednicu tzv. teološkog modela na kojem počiva Augustinovo razumijevanje duše.

Kakva je Augustinova duša u trenutku kad piše, kako opisuje sadržaj X. knjige Ispovijesti? — Ona je mirnija nego prije, ${ }^{11}$ a mirnija je, budući da je ispovijedala grešnost prošlog života, odnosno života prije obraćenja. No, ona još uvijek nije u stanju potpunog blaženstva, jer predstoji njezino očitovanje u sadašnjem trenutku. I to očitovanje u sadašnjosti Augustin započinje »priznavanjem«, tj. ispoviješću. »Priznavanje« ili »ispovijest « neka bude druga polazišna točka teološkog modela pomoću kojega nastojimo protumačiti Augustinovu koncepciju duše, ali, ne samo to, nego konstelaciju njegove vlastite duše, koja se čas raduje, čas je žalosna, čas je izgubljena, a čas (pro)nađena.

Sadržaj 2.-4. glave X. knjige Ispovijesti vrlo je bitan za tumačenje i razumijevanje Augustinova pojma ispovijesti, ali i za razumijevanje stanja njegove vlastite duše, kao i njegova učenja o duši. Augustin u 2. glavi X. knjige na jednom mjestu

10 Aurelije Augustin, Ispovijesti, X., 6.

11 Tu mirnoću možemo vizualizirati jednim mjestom iz Ispovijestima, gdje Augustin kaže: »nemirno je srce naše dok se ne smiri u tebi«. - Isto, I., 1. . Augustin time tvrdi da čovjek potpunu smirenost, odnosno, aristotelovski pojmljeno, blaženstvo može postići jedino u Bogu. Također je riječ o jednom bitnom mjestu u Ispovijestima, koje može poslužiti za dublje i složenije analize Augustinova shvaćanja i tumačenja Boga kao »kuće mira«. No, svakako da to gledište valja pojmiti u dijaloškom smislu. 
kaže da je »sâm sebi mrzak, da sebe odbacuje«, jer se sâm sebi ne želi svidjeti (kao takav) osim po Bogu. Tu se nameće pitanje kako teološki protumačiti odbacivanje sebe u ime Boga? Nije li takvo što u perspektivi teologije shvaćeno kao čin protiv samoga Boga, ako je Bog — kako kaže Augustin — intimior intimo meo? - Augustin ne govori o odbacivanju svoje osobe, odnosno karaktera u cijelosti, nego o odbacivanju grešnog dijela života, jer njegova duša i misli vape za (samo)očitovanjem, odnosno za priznavanjem svega onoga nad čim se on kao razumsko biće gnuša. Augustin se upravo gnuša nad svojim prošlim životom, jer — kako sâm za sebe metaforički kaže — »još se u tridesetoj godini bio valjao $\mathrm{u}$ istom blatu ${ }^{12}$ Premda je u to vrijeme (točnije oko tridesete godine života) težio za blaženim životom, mislio je da će biti odveć bijedan ako, između ostalog, bude lišen zagrljaja žene. ${ }^{13}$ Augustin je u određenim periodima života bio u velikim dvojbama, poglavito što se tiče odnosa sa ženama. Te su dvojbe, psihološki pojmljeno, produkt njegove unutarnje borbe vođene između razuma i strasti; duha i tijela, jer je evidentno - kako izvješćuju Ispovijesti — da je Augustin s jedne strane bio čovjek nagona - freudovski mišljeno libida, a s druge strane, u kasnijoj fazi života postao je vrlo pobožan i bogobojazan. Takvo Augustinovo unutarnje nemirno stanje uzrokovano svjesnošću o promašenosti ${ }^{14}$ mladenačkog života očito je moralo u jednom trenutku eskalirati i izići na vidjelo. To se zaista dogodilo, kako je razvidno iz sadržaja X. knjige Ispovijesti, poglavito iz prvih redaka, gdje napokon Augustin započinje s priznavanjem svojih grijeha, ali ne u ekleziološkom smislu (po sadržaju, broju i strukturi grijeha), nego u etičkom (po savjesti). Proces »ozdravljenja « Augustinove nemirne duše dugačak je i složen, dakle, ne događa se preko noći, nego korak po korak, dokle god Augustin ne »očisti« svoju dušu od grijeha prošlog života. U tom procesu Augustin se samopreispituje, analizira, osluškuje, važe što mu drugi govore i kako mu govore. ${ }^{15}$ Nakon stanja ispunjenog dvojbama, strepnjama i strahovima, Augustin je napokon pronašao lijek za svoju »bolest «: uslijedilo je dugo očekivano obraćenje. ${ }^{16}$

Posljednji dijelovi VIII. knjige Ispovijesti od velike su važnosti za prepoznavanje i shvaćanje Augustinova razumijevanja duše. U tom pogledu, u sadržaju VIII. knjige Ispovijesti poglavito valja izdvojiti glave od 9. do 12., gdje Augustin progovara o pitanju volje i sukoba koji se događa u njegovoj duši, a to nas uvodi u sljedeći model razumijevanja Augustinove psihologije.

12 Aurelije Augustin, Ispovijesti, X., 6.

13 Isto, VI., 11.

14 Misli se grješnosti — analizirajući svoj prošli život, dakle, život prije obraćenja, Augustin uviđa da je tijelo to koje je griješilo, jer ga duša nije bila kadra u zadanom trenutku upraviti. Tu je bjelodan platonizam.

15 Pod »drugima« se misli na neke osobe iz Augustinova života zahvaljujući kojima se Augustin odlučio obratiti: milanski biskup Ambrozije, prijatelj Alipije, Simplicijan, koji mu pomaže pronaći način kako se obratiti. Aurelije Augustin, Ispovijesti, VIII., 1-3.

16 Isto, VIII., 3-4. Izraz »bolest « je tek kolokvijalno uzet i njegovo značenje valja tumačiti u odnosu na opisani kontekst. 


\subsubsection{Psihološki model}

Za Augustina duša je ona koja zapovijeda tijelu, ali i sebi samoj. ${ }^{17}$ Duša upravlja kompletnom čovjekovom unutarnjom i vanjskom aktivnosti: duša zapovijeda da se pokrene ruka; ona zapovijeda tijelu kad nešto hoće, i ne bi zapovijedala — tumači Augustin — kad ne bi htjela. No, u tom shvaćanju načina na koji duša djeluje u samom čovjeku Augustin nešto uočava - uočava da čovjek ne izvršava ono što duša zapovijeda. Uzrok? - Uzrok leži u činjenici da duša djeluje po principu volje: duša ne bi zapovijedala kad ne bi htjela, a, i kad zapovijeda, ona zapovijeda koliko hoće. - Kako vidimo, kod Augustina se djelovanje duše isprepliće s voljnim djelovanjem, i u tom smislu, zahvaljujući sadržaju 9. glave VIII. knjige Ispovijesti, može se zaključiti da, glede unutarnjih čovjekovih procesa, Augustin daje primat volji, »jer volja zapovijeda da se vrši volja«. No, volja ipak ne zapovijeda potpuno, jer kada bi bila potpuna — shvaća Augustin — »ne bi zapovijedala da bude, jer bi već bila«. Takav nepotpuni proces koji obavlja volja jest, zapravo, bolest duše »što se ne uzdiže čitava, nego je istina podiže, a navika pritišće«. Na temelju tih analiza Augustin zaključuje da u čovjeku postoje dvije volje, »jer ni jedna od njih nije potpuna, nego jedna ima čega druga nema «. ${ }^{18}$ Tim smo tumačenjem Augustinova razumijevanja djelovanja volje došli do treće odrednice psihološkog modela, prema kojemu nastojimo protumačiti Augustinov pojam duše: volja. Dakle, volja nije shvaćena kao ona koja ima primat nad dušom, nego njezino nepotpuno djelovanje Augustin shvaća kao bolest duše.

Premda se naizgled čini da su unutarnje dvojbe napokon napustile Augustina, međutim, one se nastavljaju. Već nam sadržaj 10. glave VIII. knjige Ispovijesti daje sasvim drukčiju sliku Augustinova psihičkog stanja i drukčije tumačenje volje u odnosu na prethodno. U tom dijelu Ispovijesti Augustin osuđuje sve one koji misle da postoje dvije volje: »Neka izginu pred licem tvojim ${ }^{19}$ [...] oni koji vide dvije volje kod odlučivanja ${ }^{20}$

Kako Augustin argumentira postojanje jedne volje i jedne duše? - Argumentira iz perspektive vlastitog iskustva, opisujući svoje unutarnje stanje, kada je odlučio - kako sâm kaže — stupiti u Božju službu. U vrijeme kada je Augustin odlučio učiniti taj korak (na što ga je vjerojatno nagovorio njegov prijatelj Alipije, koji ga je usput odgovarao od ženidbe — kako se dadne zaključiti iz sadržaja od 10. do 15. glave VI. knjige), on je to malo htio i malo nije htio. ${ }^{21}$ To stanje

17 Aurelije Augustin, Ispovijesti, VIII., 9.

18 U pozadini spomenutoga govora o dvije volje nazire se manihejski pristup, jer je Augustin devet godina bio manihejac, a manihejstvo polazi od načela dualnosti. No, ipak se čini kao da Augustin u 9. glavi VIII. knjige ironizira manihejsko učenje o dvama počelima u čovjeku, negoli što uistinu tako misli, jer već u 10. glavi iste knjige opovrgava ono što je prethodno rekao.

19 Tu Augustin misli na Boga, što je razvidno u nastavku misli koju smo namjerno izostavili, stavljajući naglasak na onaj dio misli u kojem Augustin donosi osudu mišljenja opisanog u 9. glavi VIII. knjige.

20 Aurelije Augustin, Ispovijesti, VIII., 10.

21 Isto. 
neodlučnosti izazvalo je unutarnju borbu, o kojoj Augustin izričito i jasno govori da se to cijepanje zbivalo protiv njegove volje, a takvo je stanje smatrao kaznom svoje duše. ${ }^{22}$ Drugim riječima, iz psihološke perspektive gledano, čovjeka njegova duša kažnjava svaki put kada on nije u stanju donijeti odluku. Tu neodlučnost Augustin naziva kaznom koju duša odašilje tijelu jer je grješno. Prema tomu, izvor tog »cijepanja« Augustin vidi u grijehu koji prebiva u njemu. ${ }^{23}$

Vjerojatno Augustin, i pored svojih analitičkih sposobnosti potkrijepljenih izuzetnom retorikom, nije poznavao drukčiju terminologiju kojom bi protumačio mehanizam djelovanja volje u stanju neodlučnosti, stoga se poslužio kršćanskim tumačenjem, Pavlovim, ${ }^{24}$ prema kojemu je »smrtno tijelo« (grč. sárks) izvor grijeha i afekata. Tu se nazire i Platonov nazor o duši, prema kojemu je tijelo shvaćeno kao tamnica duše, no Augustin, glede shvaćanja suodnosa duše i tijela, ipak ne ide u krajnost, kao što je to učinio Platon. Augustin zagovara jedinstvo tijela i duše, što je svojstveno kršćanskomu nazoru o čovjeku, koji je bliži aristotelizmu. Stoga je Augustinovo poimanje tijela kao nečeg što je grješno i propadljivo za njega samog samorazumljivo, a s tog se gledišta njegovu filozofsku misao može odrediti kao neoplatonizam protumačen i shvaćen na kršćanski način. U svakom slučaju, valja reći da je Augustin vrlo kritičan prema sebi samomu. Njegove Ispovijesti u suštini predstavljaju pravo priznanje i očitovanje onih vlastitih čina kojih se Augustin u zreloj fazi svojega života srami i gnuša se nad njima, iako je nerijetko riječ i o malim grijesima (poput krađe voća iz susjedovog vrta i sl.).

Glede antropološko-moralne kvalifikacije, za Augustina se može reći da mu je upravo spoznaja vlastite grešnosti omogućila spoznaju vlastite osobe i spoznaju Boga. Oštroumnost, obrazovanost, načitanost - sve je to Augustinu pomoglo pri oblikovanju vlastite kritičke svijesti do točke u kojoj ta kritička samosvijest postaje puko čovjekovo osobno priznanje, štoviše, teološki razumijevano, osuda vlastitih djela i čina. Stoga se može govoriti i o etičkoj komponenti Ispovijesti, koja počiva na spoznaji da savjest ipak može upraviti volju i nagon, a Augustin je to upravo potvrdio svojim životnim izborom, opredijelivši se u potpunosti za službu Gospodnju i postavši biskup u Hiponu. Možda je tim životnim izborom želio pokazati i dokazati da »suze njegove majke Monike« nisu bile uzaludne i da su njezine molitve uslišane. ${ }^{25} \mathrm{Je}$ li tom Augustinovom konačnom životnom izboru prethodio inat ili — teološki rečeno - milost po vjeri, pitanje je na koje nije jednostavno odgovoriti, no, na temelju onoga što on sâm kazuje u svojim ispovijestima, može se zaključiti da njegov izbor, kao i obraćenje, imaju itekako veze s osobnom voljom.

22 Isto.

23 Isto.

24 Aurelije Augustin, Ispovijesti, VII., 21.. Augustin je osobito cijenio i volio Pavla kao pisca koji mu je otkrio Krista. Glede teologije tijela, Augustin se poziva na Rim 7,24, gdje se Pavao pita tko će čovjeka osloboditi od smrtnog tijela, ako ne milost Božja.

25 Augustinova majka Monika odigrala je važnu ulogu u Augustinovu životu. Njezino se ime višekratno spominje u Ispovijestima. Aurelije Augustin, Ispovijesti, III., 11.; VI., 1-2., 13.; IX., 9., 10. 11 . 
Prethodno je izlaganje bilo usmjereno na propitivanje glavnih odrednica teološkog i psihološkog modela, shvaćenih kao spoznajni stupovi na kojima počiva Augustinovo shvaćanje i razumijevanje duše. Nedostaje još jedan stup — nazovimo ga tzv. spoznajnim modelom, koji je nezaobilazan kada je riječ o Augustinovu tumačenju čovjeka.

\subsubsection{Spoznajni model}

Je li se Augustin nakon obraćenja uistinu promijenio i postao homo novus, koji je sebe spoznao u svjetlu »vječne istine « (tj. u Bogu) kao potpunog čovjeka, ili je riječ o nečem sasvim drugom, za što je teško pronaći drukčiji izraz od onoga koji dohvaćamo u pojmu obraćenja? Da bismo uopće mogli provesti detaljnu analizu Augustinove osobe, potrebno je proniknuti u konstrukciju i mehanizam njegova karaktera. Drugim riječima, potrebno je, kako bi Freud kazao, provesti detaljnu psihoanalizu, ne bismo li otkrili uzroke obraćenja Augustinove osobe/ ličnosti. Prionemo li pomnomu i detaljnomu čitanju Ispovijesti, vidjet ćemo da njihova cjelokupna formalna konstrukcija po metodi i instrumentariju nalikuje strukturi i konceptu Freudove psihoanalize, na temelju čega zaključujemo da je Freud taj koji je "prisvojio « Augustinovu misaonu konstrukciju i preslikao je u svoje učenje o analizi duše. Dakle, redoslijed i tijek Augustinovih misli podsjeća na autoopservaciju, a instrumentarij kojim se Augustin služi kako bi obrazložio svoje misli je razgovor koji je u biti govor, jer Bog je njegov slušač. Može se reći da Augustin opservira svoje psihičko stanje, odnosno, svoju ličnost, i te opservacije u formi priznavanja grijehâ iznosi u formi razgovora s transcendentnim bićem Augustin se Bogu obraća u 2. licu jednine. U tom smislu, odnos između Augustina i njegovog transcendentnog bića - Boga, u perspektivi freudovske terminologije načelno možemo pojmiti kao razgovor i odnos između pacijenta i terapeuta/ liječnika. Zašto se Augustin toliko bavi analizom svoje ličnosti? — Odgovor leži među redcima Ispovijesti. Augustin, naime, »proučava « sebe ne bi li tako spoznao Boga, a s druge pak strane, »proučava« Boga, ne bi li spoznao sebe sama. Augustin je proniknuo u svoj unutarnji sklop, gdje je pronašao samo strepnje, strahove, nemir i sumnje. Štoviše, može se reći da ga je detaljno i spoznao; jer kako bi, u suprotnom, mogao spoznati Boga, ako prethodno ne spozna sebe? Prema tomu, spoznati sebe, prema Augustinu, znači spoznati Boga i obratno: spoznati Boga znači spoznati sebe kao razumsko, konačno, smrtno i nesavršeno biće. Mnogo stoljeća nakon Augustina, na sličan je način novovjekovni francuski mislilac Blaise Pascal protumačio čovjeka, rekavši da čovjeka moramo poznavati da bismo ga voljeli, a Boga najprije moramo voljeti da bismo ga poznavali.

Da razjasnimo neke eventualne dvojbe koje se mogu pojaviti na horizontu mišljenja i razumijevanja kada je riječ o Augustinovu razumijevanju čovjeka i Boga, što predstavlja neizostavnu poveznicu u pristupu Augustinovoj psihologiji.

Augustin je teolog, filozof, antropolog, psiholog i pisac. U središtu njegove filozofske misli jesu Bog i čovjek. Augustinove Ispovijesti svojevrsna su analiza njegova duševnog, ili kako on sâm kaže, unutarnjega stanja te predstavljaju svojevrsni traktat o samospoznaji, gdje su opisani: a) metoda kojom se dolazi do 
samospoznaje: opservacija ili promatranje vlastite nutrine; b) instrumentarij koji je potreban da bi se metoda realizirala: razgovor; c) okolnosti koje određuju i uvjetuju stanje duše: život u cjelini. Kad Augustin govori bilo o čemu, on govori sveobuhvatno, te su kod njega bitne značajke nekog problema gotovo uvijek promatrane iz nekoliko aspekata, stoga je i samorazumljivo zbog čega, kada je primjerice riječ o spoznavanju njegove vlastite duše, govorimo o teoriji spoznaje, teologiji ili sl. Ispovijesti, kao temeljni izvor na koji se ovdje pozivamo, kada je riječ o razumijevanju i tumačenju Augustinove koncepcije duše, predstavljaju sukus njegova učenja istovremeno o Bogu i o čovjeku, i o svemu onom što ulazi pod zajednički nazivnik tih dvaju pojmova, i što prvo veže uz drugo i obratno - a to je - u ovom slučaju — duša.

Poznavanje čovjeka, kako je mislio Augustin, vezano je za poznavanje njegove nutrine, tj. duše. Za Augustina duša je supstancija obdarena mišljenjem, a njezina je narav takva da uređuje tijelo, odnosno, da uspostavlja unutarnji balans.

Augustin je doista pridao veliku važnost ulozi duše u odnosu na čovjekovu cjelokupnu egzistenciju, koja je određena okvirima zadanog prostora i vremena. Vrijeme se, prema Augustinu, mjeri u duši, jer duša je sa svojim utiscima i čuvstvima mjesto u kojem ostaju prošle stvari i gdje se mjere ti utisci uzrokovani od stvari koje prolaze: »U tebi, dušo moja, mjerim vrijeme«— kaže Augustin. ${ }^{26} \mathrm{U}$ duši se objedinjuju sve tri komponente vremena: prošlost, sadašnjost i budućnost. Sadašnjost u sadašnjosti označuje gledanje; sadašnjost u prošlosti je pamćenje, a sadašnjost u budućnosti je očekivanje. ${ }^{27}$ Gledanje, pamćenje i očekivanje asimiliraju se u jedno: u neizvjesnu sadašnjost u kojoj čovjek spoznaje vlastitu egzistenciju kao konačnu i krhku. Dočim o tome počne misliti, u njegovoj se nutrini, psihološki pojmljeno, javlja rasap ličnosti, uzrokovan strahom i strepnjama pred Božjom beskonačnošću, s jedne strane, i spoznajom o vlastitoj bijedi, s druge strane. To je »pravi« čovjek, sa svojom »pravom« dušom, kojoj je dopušteno da se boji, da sumnja, da voli itd.

Freudovim načinom mišljenja obojena koncepcija o čovjeku i duši, ne da ne poznaje, nego ne priznaje izraze poput obraćenja, a na fenomene koji imaju veze s »religioznim osjećajem « (W. James) gleda kao na stanovitu anomaliju koja je zahvatila dušu nekog čovjeka.

\section{Duša rastumačena Freudovim pogledom na čovjeka}

\subsection{O osnovnim karakteristikama Freudove koncepcije psihoanalize}

Čovjekovi unutarnji mehanizmi upravljeni su dvama nagonima: seksualnim nagonom ili libidom i nagonom za agresijom. Kad se čovjekov ego više ne može opirati vanjskim okolnostima koje ga koče i počinju sputavati, čovjek pada u 
stanje neuroze. - Tim pojednostavljenim riječima možemo opisati Freudovo poimanje unutarnjeg ili duševnog sklopa ličnosti, odnosno osobe.

Što je libido? - Prema Freudu, libido je seksualni nagon, požuda, ono iskonsko, životinjski u čovjeku, koje je uzrok svih neuroza i psihoza. Da bi se čovjek riješio ili oslobodio stanja neuroze, potrebno mu je liječenje. No, tu nije riječ o bilo kakvom liječenju, pogotovu ne onom kliničkoga, predfreudeovskog tipa, nego o liječenju kroz razgovor. Čovjeka koji boluje od neke vrste neuroze valja izliječiti na način da se provede kompletna analiza njegove duše — po Freudu, psihoanaliza: nova metoda liječenja neurotičnih bolesnika putem opservacije i razgovora s bolesnikom. Klinička psihijatrija, koju je Freud toliko kritizirao, jer nije bila kadra uz pomoć svojih metoda detaljno prodrijeti u psihički sklop i mehanizam ličnosti, nije prikladna terapija koja bi izliječila čovjeka koji boluje od neke vrste neuroze. ${ }^{28}$ Stoga Freud smatra neophodnim pronaći adekvatnu terapiju za bolesnu dušu.

Psihoanaliza, kako Freud tumači, nije neki spekulativni sistem, nego je iskustvo ili direktno promatranje. ${ }^{29}$ Ono što je karakteristično za Freudovo razumijevanje duše zapravo predstavlja ujedno i prigovor njegovoj metodi kao i samom učenju. Važno je spomenuti da Freud, kada govori o čovjekovoj duši, ima na pameti bolesnu, a ne zdravu psihu, što je, naravno, posljedica njegove dugogodišnje kliničke prakse s bolesnima. Bolesna se duša može manifestirati na različite načine, koji isprva ne izgledaju kao odstupanje od normale, a među to potonje, prema Freudu spadaju pogreške u govoru i pisanju, snovi, tzv. lude ideje ljubomore itd. Sve to predstavlja bolesna stanja čovjekove duše, koja svoj uzrok imaju u nesvjesnom. Freudova je dijagnoza da čovjekovom osobom, odnosno, ličnošću vlada nesvjesno te se pita: Ima li ego pored snažnog intenziteta nesvjesnog vlastitu autonomiju i funkciju, ili on uvijek služi ciljevima i motivima koji leže duboko u nesvjesnom? - Freud u odgovoru na to pitanje ipak daje prvenstvo nesvjesnomu, a nesvjesno tretira kao primarni proces. Zbog toga mu se pripisuje jedno od najvećih otkrića moderne psihologije: otkriće nesvjesnog, čime je uvelike doprinio psihologijskoj znanosti, ali i razumijevanju koncepta identiteta. Zahvaljujući Freudu, svaki čovjek danas zna da u sebi nosi nesvjesne osjećaje, koji bi ga itekako iznenadili, kad bi za njih saznao.

Budući da smo ukratko iznijeli glavne odrednice koje konstruiraju Freudovu psihologiju (a to su, da se podsjetimo: libido, nesvjesno i primarni procesi), sada valja reći ponešto i o funkciji tog »nesvjesnog $«$.

28 Freud smatra da se psihoanaliza odnosi prema psihijatriji kao histologija prema medicini; jedna proučava vanjske oblike organizma, druga njihov sastav iz tkiva i elementarnih dijelova. - Sigmund Frojd, Uvod u psihoanalizu, Novi Sad - Beograd, 1984, str. 238.; također usp. tuzemni prijevod: Sigmund, Freud, Predavanja za uvod u psihoanalizu, Zagreb, 2000. (Autorica se služila beogradskim izdanjem, poradi tehničke nedostupnosti hrvatskog prijevoda spomenutog Freudova djela).

29 Sigmund Frojd, Uvod u psihoanalizu, str. 228. 


\subsection{Duša u kontekstu nesvjesnog}

Za Freuda nesvjesno ili id označuje dvoje: (1) »mjesto« u kojem su nagomilane ili potisnute uspomene, koje su ispuštene ili bačene u dubok ponor; (2) nesvjesno je izvor energije, instinktivni nagon (libido i agresija). Taj id funkcionira po principu zadovoljstva te ne priznaje nikakvu vanjsku stvarnost. Ego služi idu. Za razliku od ida, ego funkcionira po principu stvarnosti uz pomoć tzv. sekundarnih procesa. Dužnost ega je racionalne naravi: rješavanje problema, mišljenje, planiranje i zaštita ida. Ego je posrednik između instinkta i vanjskog svijeta.

Sve što je prethodno rečeno, zvuči lijepo i harmonično, dok se ne pojavi blokada zbog koje ego više nije u stanju vršiti svoju funkciju. Tu blokadu mogu uzrokovati sukobi, frustracije i strahovi, zbog kojih, ako potraju, čovjek zapada u neurotično ponašanje, tj. njegova ličnost postaje poremećena. Neuroza nastaje jer ego, koji svoju energiju uzima od ida i izvršava njegove impulzivne naredbe, nailazi na otpor iz vanjskog svijeta te zbog toga više ne može upravljati vanjskim svijetom. Prema Freudu, uloga psihoanalize je omogućiti bolesnomu da pojača svoj ego time što će proširiti njegov volumen na način da ego suoči s opasnim mislima. Stoga je i Freudov moto psihoanalize glasio: »Gdje je bilo id, tamo će biti ego. $\ll^{30}$

Vidjeli smo na kojim osnovicama počiva Freudova psihologija i što Freud podrazumijeva pod psihoanalizom. No, jedno je ipak ostalo nedorečenim: pojam duše. Kako Freud razumijeva dušu? — Za Freuda duša nije nikakvo počelo (Aristotel), ni supstancija obdarena mišljenjem (Augustin), ni nikakva religiozna poveznica (W. James). Na temelju prethodno izloženog dalo bi se zaključiti sljedeće: za Freuda je duša ono nesvjesno ili izvor nesvjesnih procesa. Nesvjesni procesi su primarni psihički procesi, kako smo već ranije rekli, a čovjek ih osvješćuje kad se suoči s onim potisnutim, te na taj način on upoznaje samog sebe $\mathrm{u}$ »svim svojim dubinama i bezdanima « — kako kaže Hans Küng. ${ }^{31}$

\subsection{Augustin i Freud: konvergencije i divergencije}

Nesvjesno, bezdan, dubina zapravo su Freudovi sinonimi za ono što Augustin podrazumijeva pod pojmom duše. Stoga možemo reći da se Freudovo tumačenje duše od Augustinova razlikuje ponajprije nominalno.

Prva dodirna točka koja analogno povezuje Augustina i Freuda jest upravo Freudov temeljni pojam: psihoanaliza. Pojam psihoanalize Augustin ne rabi u spomenutoj formulaciji, ali metoda kojom se koristi na putu samospoznaje ili spoznaje vlastite nutrine - duše, dakle, metoda interiorizacije ili »pounutarnjenja psihoanalize: introspekcija. Augustinova metoda interiorizacije kao prvi korak samospoznavanja ili spoznavanja vlastitog »ja «, tj. nutrine u prvom licu jednine,

Gordon Willard Allport, Sklop i razvoj ličnosti, Beograd 1969, str. 194. [Prezime autora na naslovnici: Olport.]

31 Hans Küng, Postoji li Bog? : Odgovor na pitanje o Bogu u novome vijeku, Zagreb, 1987, str. 250. 
i Freudov princip na kojem počiva tzv. introspekcija temelje se na opservaciji. U tom smislu opservaciju bismo mogli uzeti kao drugu dodirnu točku, koja barem nominalno povezuje Augustinovu i Freudovu psihologiju. Treća dodirna točka koja bi mogla povezati Augustinovu i Freudovu psihologiju jest razgovor. Za Augustina, kao i za Freuda razgovor predstavlja instrumentarij uz pomoć kojeg se čovjek kadra osloboditi svojih najdubljih strepnji, želja, tajni, osjećaja i sl., zapravo, osvješćuje ono nesvjesno u čovjeku. Četvrta dodirna točka, kada je riječ o razumijevanju i tumačenju i Augustinove i Freudove psihologije predstavlja uistinu onu zajedničku poveznicu: to je stav obojice da čovjek, da bi sebe spoznao, mora najprije poznavati svoju nutrinu (takvo je stajalište zastupao i Sokrat). Augustin to izrijekom tvrdi, dok se to isto dadne zaključiti i kod Freuda, koji je pridao veliku važnost nesvjesnomu kod čovjeka, i ono što smo naveli u prethodnim redcima, da današnji čovjek, psihologijski pojmljeno, poznaje svoju nutrinu zahvaljujući Freudovom otkriću nesvjesnoga.

Divergencije na liniji Augustin-Freud podrazumijevaju i sljedeće divergentne osobitosti, do čijih se uvida došlo uz pomoć detaljne analize strukture i sadržaja Augustinovih Ispovijesti i relevantnih izvora koji podastiru uvide o Freudovu konceptu psihoanalize shvaćene kao terapeutske metode koju detaljno opisuje u djelu Uvod u psihoanalizu.

Prvo, kada je riječ o svjetonazoru, obrazovanju, izboru službe, jedan je bio humanist a drugi prirodoznanstvenik. Augustin je bio pravnik, filozof, biskup i službeni naučitelj kršćanske, katoličke doktrine, dok je Freud po struci bio liječnik, kliničar, psihijatar. Govorimo o temporalnom aspektu koji diktira njihov navlastiti kulturni, misaoni - svjetonazorski milje: rani srednji vijek nasuprot modernomu dobu; povijesno-društvene uvjetovanosti: kod Augustina posrijedi je prevalentnost onoga što Taylor u svojoj Etici autentičnosti naziva »starim moralnim obzorima naspram Freudova pozitivističkim jezikom oblikovane »metafizike svijesti « - sfera nesvjesnoga.

Drugo, kada je riječ o religijski impostiranom uvjerenju, dakle vjeri, Augustin je teist, a Freud ateist. Poznato je Freudovo tumačenje Boga kao infantilne iluzije. Dakle, dvije različite religiozne (i svjetonazorske) pozicije.

Treće, s obzirom na doktrinarno opredjeljenje, Augustin se tijekom života od manihejca obratio u prosvijećenog mislioca i kršćana.

Četvrto, teološki gledano, Augustinov čin obraćenja valja sagledati u svjetlu etike poziva i Božje milosti.

Peto, za razliku od Augustina, Freud je čitav život proveo u kliničkim istraživanjima i radio s pacijentima.

Nabrajajući u kojim se segmentima, glede razumijevanja koncepcije duše, Augustin i Freud podudaraju ili pak razilaze, izostala je još jedna bitna stvar, koja predstavlja »kamen temeljac« njihova učenja o duši. »Najzajedničkija «stvar, da se izrazimo gramatički diskrepantno, jest ta da, štogod mnogi o njoj mislili, ona ostaje prihvatljivom činjenicom: psihologija. I Augustin i Freud su psiholozi, s jednom razlikom: Augustina je težnja za spoznavanjem Boga odvela na put psihologije, a Freuda je tendencija da iznađe metodu uz pomoć koje bi pomogao 
bolesnomu čovjeku koji pati od neuroze odvela na put spekulativnog mišljenja. Što li je drugo duša, negoli supstancija obdarena mišljenjem?!

\section{Namjesto zaključka}

U ovom radu bavili smo se mogućnošću utvrđivanja, postojanja i dokazivanja dodirnih točaka između Augustinove i Freudove koncepcije duše, odnosno, psihologije, polazeći od tvrdnje da je Freud u temelju augustinovac. U filozofskom miljeu spomenuta se tvrdnja još donekle i može prihvatiti, no onaj suprotni tabor - psiholozi i psihijatri spomenutu će tezu naći apsurdnom. Potonja misao nije preuzetna, jednako kao što niti ovi redci nisu nastali odjednom, već su oblikovani i pisani u vremenu, slojevito, a poradi razloga da je bilo od neophodne važnosti proučiti relevantne izvore, odnosno, literaturu koju se konzultiralo tijekom pisanja ovoga rada. Dakako, među autorima kompetentnima za tumačenje Freudova učenja nije se pronašao nijedan argument koji bi išao u korist naše teze, ali, kako je bilo i za očekivati, argument se pronašao u literaturi filozofsko-literarne provenijencije, osobito kod autora koji se bave narativnim teorijama, a koje smo citirali ovdje. Razumijevanje onoga što dohvaćamo pojmom duše traži dubok i jasan uvid u genezu i suštinu onih teorija i učenja u povijesti filozofske misli koje su navlastito obilježile diskurs o duši, ne samo na povijesnoj nego i na metaetičkoj razini. Duša je Augustinu potrebna kako bi došao do Boga, a Freudu, kako smo vidjeli, pojam duše uopće ne treba niti se on njime eksplicitno bavio. Primarni objekt Freudovih istraživanja vezan je za klinički, terapeutski proces liječenja anomalija čovjekove nutrine, uzrokovanih neurozama različitih tipova i intenziteta, s jedne strane, i razumijevanje načina na koji funkcionira ljudski um, s druge, tako da možemo govoriti prije o freudijanskoj psihologiji uma, negoli o psihologiji u klasičnom smislu te riječi. Ovo naše istraživanje dodirnih točaka koncepcija o duši ranije spomenutih autora predstavlja samo pledoaje temi koja u sadržajnom, metodološkom i epistemološkom pogledu predstavlja neiscrpan izvor spoznaja koje su nezaobilazne u konstruiranju cjelovite slike o čovjeku i njegovu »osobnom identitetu « (Taylor). Dakako, ovdje smo samo "zagrebli« površinu tih istraživanja, kao što se »zagrebe « površina vode, kad se kamenčić baci u nju, pa se voda tek toliko uzburka, a kamenčić počne tonuti sve dok ne dotakne dno. To »dno«, metaforički, valja tek istražiti. 
The Soul in Augustine's Confessions with Special Reference to the Problem of Establishing a (Non-) Correspondence with Freud's Concept of Psychoanalysis

Dafne Vidanec*

\section{Summary}

In the content of this essay, which was methodologically envisioned as an interdisciplinary (philosophical and theological) reflection on the soul, and which (essay) epistemologically relies on cognitive-theoretical sources of two, in the opinion of the author, of the foremost authorities on the concept of soul: the philosopher, theologian, Christian scholar and bishop, from Tagaste by birth - St. Aurelius Augustine and the contemporary Austrian psychologist, »the father of psychoanalysis « and pioneer in the sphere of the unconsious - Sigmund Freud we wish to examine convergences and divergences in regard to their concepts of soul. The essay aims to answer the following: 1 ) in what way does Augustine understand the concept of soul, what is his starting point and wherein is his understanding of soul founded? 2) in what measure and in what way is/was his teaching on soul, as expounded in his Confessions, reflected in Freud's explanation of soul, understood by the latter as the locus primus in the study of causes and effects of neuropathological phenomena in clinical practice as described in detail and elucidated in his Introduction to Psychoanalysis? The essay is structured as follows: the first section aims, from the theological and cognitive aspects, to examine the basic tenets of Augustine's understanding and explanation of soul, but in the spirit of Fichte's qualis homo, talis philosophia. The second section of the essay focuses on the author's interpretation of Freud's psychoanalysis as a therapeutic method by means of which man's "sick soul « or rather "personality" according to Freud, is not only studied but healed (Allport). The content of the third section deals with the convergences and divergences of Augustine's and Freud's »theo-psychoanthropology", for that which is common to Augustine and Freud is the focus of their research, and that is man : for Augustine, exploring (revealing) the soul is the path to seeking (discovering) God such that we are dealing with a psychology which issues from ascendent theology and, on the other hand, exploring (revealing) of the unconscious part of Aristotle's »reasonable souls « in the Freudian manner is the path to exposing man's personal identity (selfhood) : man is the starting point in the search for God (i.e. the source of good), but of the self also (St. Augustine, Ch. Taylor).

Key words: Augustine, Freud, soul, psychoanalysis, man, personality, psychology

* Dafne Vidanec, Ph.D., Baltazar College, Zaprešić. Address: Vladimira Novaka 23, 10290 Zaprešić, Croatia. E-mail: dafne.vidanec@gmail.com 